\title{
DEIKSIS DALAM BAHASA DAYAK DEAH
}

\author{
Isna Kasmilawati \\ STKIP PGRI Banjarmasin
}

\begin{abstract}
Abstrak
Deiksis merupakan bentuk bahasa yang tidak memiliki acuan yang tetap sehingga maknanya sangat bergantung pada konteks kalimatnya. Dalam ujaran deiksis mempunyai peranan penting, sehingga lawan bicara dapat memahami ujaran tersebut, yang antara lain melalui konteks. Setiap konteks lisan maupun tulisan memliliki latar belakang, tujuan pembicaran dan tempatnya. Peristiwa yang dibicarakan dalam konteks ujaran akan berubahubah tergantung situasi ujarannya

Subjek penelitian ini, yaitu a) suku asli Dayak Deah, b)berbahasa Dayak Deah dalam kehidupan sehari-hari, c) berumur minimal 40 tahun, dan f) berdomisili di Desa Pangelak. Metode yang digunakan dalam penelitian ini adalah metode deskriptif. Penggunaan metode deskriptif dalam penelitian Deiksis dalam Bahasa Dayak Deah sangat sesuai dengan tujuan penelitian dan mudah digunakan. Teknik pengumpulan data dilakukan dengan teknik wawancara, observasi, dokumentasi.

Hasil penelitian ini adalah sebagai berikut. (a) wujud deiksis orang dalam bahasa Dayak Deah, (b) wujud deiksi waktu dalam bahasa Dayak Deah, (c) wujud deiksi tempat dalam bahasa Dayak Deah, dan (d) wujud deiksis sosial dalam bahasa Dayak Deah.
\end{abstract}

Kata kunci: deiksis, bahasa Dayak Deah 


\section{PENDAHULUAN}

Bahasa merupakan alat untuk berkomunikasi antara penutur dan mitra tutur di dalam kehidupan sehari-hari yang memiliki maksud dan tujuan tertentu. Bahasa juga gejala sosial danpemakaiannya jelas banyak ditentukanoleh faktor-faktor linguistik melulu, seperti kata-kata, kalimat saja tidak cukupuntuk melancarkan komunikasi (Lubis, 2001:5).Dalam berkomunikasi pada aktivitas sehari-hari, salah satu alat yang paling sering digunakan adalah bahasa, baik bahasa lisan maupun bahasa tulis.

Deiksis merupakan bentuk bahasa yang tidak memiliki acuan yang tetap sehingga maknanya sangat bergantung pada konteks kalimatnya. Deiksis merupakan suatu gejala bahasa yang hanya dapat ditafsirkan acuannya dengan situasi dan konteks pembicaraan. Nababan dalam Rusminto (2015:24) menyatakan deiksis adalah kata atau satuan kebahasaan yang referensinya tidak pasti atau berubah-ubah. Sebuah kata pada deiksis dapat berubah berdasarkan situasi pembicaraan. Deiksis dapat juga diartikan sebagai lokasi dan identifikasi orang,objek, peristiwa, proses atau kegiatan yang sedang dibicarakan atau yang sedang diacu dalam hubungannya dengan dimensi ruang dan waktunya, pada saat dituturkan oleh pembicara atau yang diajak bicara. Deiksis dibedakan atas lima macam, yaitu deiksis persona, deiksis tempat, deiksis waktu, deiksis wacana, dan deiksis sosial (Cummings, 2007:31).

Unsur deiksis dalam kehidupan sehari-hari digunakan dalam bahasa lisan dan tulisan. Dalam ujaran deiksis mempunyai peranan penting, sehingga lawan bicara dapat memahami ujaran tersebut, yang antara lain melalui konteks. Setiap konteks lisan maupun tulisan memliliki latar belakang, tujuan pembicaran dan tempatnya. Peristiwa yang dibicarakan dalam konteks ujaran akan berubah-ubah tergantung situasi ujarannya sendiri sehingga deiksis akan memiliki referen yang berubah-ubah atau berpindah-pindah. Deiksis adalah suatu cara untuk mengacupada hakekat tertentu dengan menggunakan bahasa 
yang hanya dapat ditafsirkan menurut makna yang diacu oleh penutur dan dipengaruhi situasi pembicaraan.

\section{METODE}

Penelitian ini menggunakan pendekatan deskriptif kualitatif,dengan maksud untuk memberikan hasil analisis data mengenai deiksis dalam Bahasa Dayak Deah. Subjek penelitian ini, yaitu a) suku asli Dayak Deah, b)berbahasa Dayak Deah dalam kehidupan sehari-hari, c) berumur minimal 40 tahun, dan f) berdomisili di Desa Pangelak.

Teknik pengumpulan data dalam penelitian ini untuk dapat menggambarkan secara objektif deiksis dalam bahasa Dayak Deah. Adapun teknik penelitian yang digunakan dalam penelitian ini yaitu.

1. Observasi langsung untuk mengetahui lingkungan penutur;

2. Wawancara

3. Teknik simak libat cakap;

4. Menerjemahkan, mengklafikasikan, mendata penutur;

5. Studi Pustaka adalah mencari dan mengumpulkan bahan-bahan referensi yang digunakan sebagai landasan teoritis dalam penelitian ini.

\section{HASIL DAN PEMBAHASAN}

\section{Wujud deiksis orang dalam bahasa Dayak Deah}

Deiksis perorangan menunjukan subjektivitas dalam struktur semantik. Deiksis perorangan hanya dapat ditangkap jika kita memahami peran dari pembicara, sumber ujaran, penerima, target ujaran, dan pendengar yang bukan dituju atau ditarget.

\section{Transkrip tuturan I}

Percakapan ini dilakukan pada saat peneliti menanyakan Indu (tante) ketika pergi ke acara repsepsi. Transkrip dilakukan secara tertulis adalah sebagai berikut. 
[1] Peneliti : : Hali sebone Indo tulak pe sepapit ende? (Dengan siapa tante pergi ke perkawinan tadi)

[2] Responden : “ Kaint ruweh tatako ka.(Kami berdua kakakmu saja)

Dalam kata Indo (tante) pada tuturan [1] merupakan kata sapaan, begitu pula dengan kata tatako (kakakmu) pada tuturan [2].konteks pembicaraan tersebut, terlihat pembicara tampak lebih muda, karena merujuk lawan bicara dengan kata sapaan Indu atau tante dan tata atau kakak. Akan tetapi, dalam konteks yang berbeda maka kata sapaan yang digunakan tersebut dapat berubah-ubah. Referen yang ditunjuk oleh kata ganti persona bergantiganti tergantung pada peranan yang dibawakan oleh peserta tindak ujaran.

\section{Percakapan 2}

Percakapan lain yang menggunakan kata tata (kakak) dapat dilihat pada percakapan berikut.

[3] Bapak : Anta pone ta? (Mau kemana ka (Kakak?)

[4] Puri : Pe warung. None ha Bah? (Ke warung. Kenapa Yah (Ayah)?

[5] Bapak : Belohka, mih mbuli suyu mamako mbuli. (Tidak ada, tapi kalau pulang suruh ibumu pulang).

Kata ta atau tata artinya kakak yang menunjukan hubungan kekerabatan. Akan tetapi kata tata menunjukkan hubungan pertalian darah, yaitu anak kandung laki-laki atau perempuan. terlihat adanya deiksis orang dalam bahasa Dayak Deah melalui kata sapaan tata/ta.

\section{Wujud deiksis waktu dalam bahasa Dayak Deah}

Deiksis waktu ialah pemberian bentuk pada rentang waktu seperti yang dimaksudkan penutur dalam peristiwa bahasa. Transkrip berikut menggambarkan tentang wujud deiksis waktu dalam penutur bahasa Dayak Deah, membuktikan bahwa Kata kletu pada percakapan [3] kalimat [6] yang artinya (saat ini), mengacu pada saat tuturan tersebut diujarkan. Farasa kletu (saat ini) mengandung makna yang kurang jelas. Frasa kletu (saat ini) bisa 
diartikan sekarang, kapan saja, bisa siang hari,dan juga bisa malam hari, tergantung kapan waktunya dituturkan dan teksnya.

\section{Catatan Cakapan 3}

Sekitar pukul 16.00 Wita di rumah salah satu warga berkumpulnya ibu-ibu (usia mereka rata-rata 38 tahun dan 40-an tahun) yang mengadakan selamatan. Percakapan mereka menggunakan BDD. Tindak berbahasa mereka yang dapat peneliti rekam secara tertulis adalah sebagai berikut.

[6] Rina : Hai, Yul. Bone kletu iko dului?(Hai, Yul. Saat ini kamu tinggal di mana?)

[7] Yuli : Alam Namun bio lih aku. (Di daerah Namun sajaa aku)

[8] Rina : Otauku ola iko beloh mbuli pe ja'a. (Lama sekali saya rasa kamu tidak pulang kekampung)

[9] Yuli : Sibuk ngani aku.(Sibuk memotong padi)

\section{Wujud deiksis tempat dalam bahasa Dayak Deah}

Deiksis tempat menyatakan pemberian bentuk kepada tempat, dipandang dari lokasi pemeran dalam peristiwa berbahasa, yang meliputi (a) yang dekat dengan pembicara (di sini); (b) yang jauh dari pembicara tetapi dekat dengan pendengar (di situ); (c) yang jauh dari pembicara dan pendengar (di sana). Deiksis ini merujuk kepada waktu berlangsungnya sebuah peristiwa. Berikut tuturan percakapan deiksis tempat dalam bahasa Dayak Deah.

\section{Catatan Cakapan 4}

\section{Topik percakapan di warung makan}

[10] Ibu mila : Tungoh riet Alma pitu? (Duduk dekat Alma di sini)

[11] Ibu Asih :Oh, andre dile engepo payung.(Oh, tunggu dulu mengambil payung) 
Pada catatan cakapan 4 frasa pitu dalam tuturan [10] yang artinya di sini menunjukkan jarak yang dekat dari si pembicara. Pada kata pitu (di sini) hanya bisa dipahami dan diketahui secara jelas tempatnya pada saat kita berada dekat dengan situasi pembicaraan atau terlibat langsung di dalam situasi pembicaraan tersebut.

\section{Catatan cakapan 5}

[12] bapak 1 : Umpi parekne biyo! (Buang sampahnya di situ)

[13] Bapak 2 : Gawisne da?(Semuanya, ya.)

[14]Bapak 1 : Umpi ka. (Buang saja)

Pada cakapan frasa biyo dalam tuturan [12] yang artinya di situ menunjukkan yang jauh dari pembicara tetapi dekat dengan pendengar. Dalam tuturan [12] tersebut tempat yang dimaksud penutur tidak jelas. Farasa biyo (di situ) dalam kata tersebut bisa diartikan ke tempat sampah atau di buang begitu saja. Dengan demikian, kata biyo (di situ) hanya bisa dipahami dan diketahui secara jelas tempatnya pada saat kita berada dekat dengan pendengar.

\section{Catatan Cakapan 6}

Peristiwa tutur ini terjadi pada saat peneliti mengumpulkan data peneliti di rumah responden.

[15] Neli : : Ontuh Indu deo esane ba denan. (Kata tante banyak ikannya di sana.)

[16] Ayu : None moko iko doho baya miwit?(Kenapa kamu tidak ikut mincing?)

[17] Neli : : Soro aku, maeh balowu.(Males aku, mending di rumah)

Pada kutipan frasa ba denan dalam tuturan [15] yang artinya di sana yang menunjukkan jauh dari pembicara dan pendengar. Farasa ba denan (di 
sana) dalam kata tersebut tempat yang dimaksud penutur tidak jelas. Dengan demikian, kata ba denan (di sana) hanya bisa dipahami dan diketahui secara jelas tempatnya oleh si penutur.

\section{Wujud deiksis sosial dalam bahasa Dayak Deah}

Deiksis sosial ialah rujukan yang dinyatakan berdasarkan perbedaan kemasyarakatan yang mempengaruhi peran pembicara dan pendengar. Perbedaan itu dapat ditunjukkan dalam pemilihan kata. Dalam beberapa bahasa, perbedaan tingkat sosial antara pembicara dengan pendengar yang diwujudkan dalam seleksi kata dan/atau sistem morfologi kata-kata tertentu (Nababan, 1987:42).

Dari hasil yang diperoleh baik secara langsung (wawancara) maupun tidak langsung melalui pengamatan dari narasumber, tidakditemukan adanya kata yang merujuk kepada jenis deiksi sosial. Dalam bahasa Dayak Deah tidak mengenal istilah bahasa yang diperluas maknanya atau menjadi lebih kasar maknanya. Sebagai contoh, mengatakan kata $A k u$ meskipun lawan bicaranya secara usia lebih tua, dalam bahasa Dayak Deah dianggap halus dan sopan.

Pada kutipan [7], tuturan [18] menyatakan bahwa aku meminta izin kepada orang lebih tua, yaitu ibu. Selanjutnya, percakapan [8] tuturan [22] menyatakan bahwa aku memberitahu kepada orang lebih tua, yaitu nenek. Akan tetapi, dalam bahasa Banjar memiliki bahasa yang maknanya dirasakan lebih halus dan terkesan lebih menghormati, begitu pula dengan bahasa Jawa. Dalam bahasa Banjar kata aku ketika berbicara dengan orang yang lebih tua, menggunakan kata ulun dan dalam bahasa Jawa menggunakan kata kulo untuk menggantikan kata aku. Sehingga, kata aku baik dalam bahasa Banjar maupun dalam bahasa Jawa dianggap kasar jika digunakan saat berbicaraa kepada orang yang lebih tua. Untuk lebih jelasnya berikut kutipan deiksi sosial dalam bahasa Dayak Deah. 


\section{Catatan percakapan 7}

Berikut ini adalah percakapan yang menggambarkan wujud deiksis sosial dalam bahasa dayak deah yang dilakukan oleh Ibu dengan Anak dan Nenek dengan Cucu (Mira).

[18] Anak : Mah, aku tulak pe lowu Mika.(Mah, aku pergi ke rumah Mika)

[19] Ibu : Oh, ayi hantap ola deh. Nindro sepada tepakai. (Iya, jangan terlalu lama. Nanti sepda terpakai)

[20] Anak : Dile ka aku. Tulak deh. (Sebentar saja aku. Berangkat ya.)

[21] Ibu : Hati-hati.(hati-hati)

\section{Catatan percakapan 8}

Peristiwa tutur ini terjadi pada saat peneliti berada dirumah salah satu warga untuk mengumpulkan data.

[22] Mira : Aku badapur. (Aku di dapur)

[23] Nenek : Mira, none ulah ko?(Mira, lagi apa?)

[24] Mira : None tak. Aku kia muluh. (Apa Nek. Aku lagi masak)

[25] Nenek : Hali itak pe Pasar, moli uyah. (Temani Nenek ke Pasar, beli beras)

[26] Mira : Oh. Andre dile.

Wujud deiksis sosial sangat berhubungan erat dengan deiksis orang dalam sebuah tuturan, yaitu melalui kata ganti orang dan kata sapaan. Dari pengamatan peneliti, tidak ditemukan kata yang maknanya lebih halus atau lebih sopan dalam tuturan bahasa Dayak Deah, baik ketika berbicara kepada yanglebih muda atau kepada yang lebih tua, sehingga yang ada hanya kata $a k u$ dan iko (aku dan kamu). 


\section{SIMPULAN}

Berdasarkan hasil penelitian dapat disimpulkan, bahwa deiksis dalam bahasa Dayak Deah dibedakan atas empat macam, yaitu deiksis persona, deiksis tempat, deiksis waktu, dan deiksis sosial. Sebuah kata dikatakan bersifat deiksis apabila referennya berpindah-pindah atau berganti-ganti, tergantung pada saat dan tempat dituturkannya kata itu. Deiksis dapat diartikan sebagai lokasi dan identifikasi orang, objek, peristiwa, proses atau kegiatan yang sedang dibicarakan atau yang sedang diacu dalam hubungannya dengan dimensi ruang dan waktunya, pada saat dituturkan oleh pembicara atau yang diajak bicara

\section{DAFTAR RUJUKAN}

Cummings, Louise.2007. Pragmatik, Sebuah Persektif Multidisipliner. Terjemahan oleh Eti Setiawati dkk. Yogyakarta: Pustaka Pelajar.

Lubis, A.Hamid Hasan. 2011. Analisis Wacana Pragmatik. Bandung: Angkasa

Nababan, P.W.J. 1987. Ilmu pragmatik (Teori dan Penerapannya). Jakarta: Proyek Pengembangan Lembaga Tenaga.

Rusminto, NurlaksanaEko.2015.Analisis Wacana. Yogyakarta:Graha Ilmu. 